\title{
Interaction of Different Dietary Levels of T-2 Toxin with Experimental Salmonella Gallinarum Infection in Broiler Chicken and its Amelioration with Arginine and Vitamin E Supplementation
}

\author{
B.K. Ramesh ${ }^{1}$, H.D. Narayanaswamy ${ }^{2}$, M.L. Satyanarayana ${ }^{3}$, \\ Suguna $\operatorname{Rao}^{3}$ and Srikrishna Isloor ${ }^{3}$ \\ ${ }^{1}$ ICAR-Krishi Vigyan Kendra, Hagari- 583 111, Ballari (Tq), Karnataka, India \\ ${ }^{2}$ Karnataka Veterinary Animal Fisheries Sciences University, Bidar, Karnataka, India \\ ${ }^{3}$ Department of Veterinary Pathology, Veterinary College, Hebbal, Bengaluru -560 024, India \\ *Corresponding author
}

\section{A B S T R A C T}

An interaction between different dietary levels of T-2 toxin and Salmonella gallinarum infection was studied in broiler chicken and the role of dietary supplementation of arginine (ARG) $[22 \mathrm{~g} / \mathrm{kg}$ ] and vitamin $\mathrm{E}$ (VE) $[80 \mathrm{mg} / \mathrm{kg}]$ in minimizing salmonella persistence in

\section{Keywords}

T-2 toxin,

S. gallinarum,

Interaction study,

Arginine, Vitamin

E, Amelioration

Article Info

Accepted:

17 March 2019

Available Online:

10 April 2019 the system was evaluated. Ninety eight day-old commercial broiler chicks were randomly allotted in equal numbers to the following groups. The Group I had two subgroupsPositive Control (PC) and Negative Control (NC) and dietary T-2 toxin level was 0.0 in both the subgroups. Groups II, III, and IV received $0.25 \mathrm{ppm}, 0.50 \mathrm{ppm}, 1 \mathrm{ppm}$ of dietary T2 toxin. Arginine $(22 \mathrm{~g} / \mathrm{kg})$ and vitamin E $(80 \mathrm{mg} / \mathrm{kg})$ were supplemented to Groups $\mathrm{V}$ and VI which respectively had 0.0 and $1 \mathrm{ppm}$ of dietary T-2 toxin. The test diets were fed for 0-35 days. Each bird in different groups excepting those of $\mathrm{NC}$ was challenged orally with $10^{7} \mathrm{CFU}$ of $S$. gallinarum on day 28 . Feed efficiency was significantly $(\mathrm{P} \leq 0.05)$ low after the salmonella challenge in all the toxin fed groups compared to PC. FCR in ARG and VE supplemented birds was similar to that of NC despite being challenged with salmonella. Birds fed with $0.5 \mathrm{ppm}$ of $\mathrm{T}-2$ toxin recorded significantly $(\mathrm{P} \leq 0.05)$ higher viable counts of salmonella in liver on day 7 PI whereas birds fed 1ppm of toxin showed higher viable counts on days 3 and 7 PI compared to positive control birds. However, ARG and VE supplemented birds recorded significantly $(\mathrm{P} \leq 0.05)$ lower viable counts on day $7 \mathrm{PI}$. The study revealed a significant interaction between T-2 toxin and S. gallinarum and dietary supplementation of ARG and VE was effective in clearing the salmonella organisms from the system.

\section{Introduction}

T-2 toxin is a highly toxic trichothecene mycotoxin elaborated by different species of genus Fusarium. The toxic effect of T-2 toxin depends on various factors such as toxin dose, duration of exposure, age of birds and presence of other mycotoxins in the feed 
(WHO, 2002). Apart from its well documented adverse effect on production performance in poultry, T-2 toxin is a potent immunotoxicant affecting both humoral and cell mediated arms of immune system. The immunosuppressive effects of T-2 toxin are the result of direct or indirect inhibition of protein synthesis (Corrier, 1991). The incidences of overt T-2 toxicosis are declining due to the rapid strides made in $\mathrm{T}-2$ toxin detection systems and the awareness created among poultry farmers. However, the harm T2 toxin may cause on the immune system of birds if it is present in levels which otherwise could cause no overt toxicity symptoms in poultry birds is of prime concern in the present scenario (Pestka and Bondy, 1990).

Fowl typhoid (FT), an OIE 2012 listed disease of poultry is a septicemic disease affecting primarily chicken and turkey and is caused by $S$. gallinarum, a gram negative non-motile bacteria. The disease is a problem of great economic concern to all phases of the poultry industry starting from production to marketing and its prevalence has been continually reported in India (Barrow and Freitas Neto, 2011; Devan Arora et al., 2015). A need to sustain the phenomenal growth that their strong genetic base offers put the commercial broilers under tremendous stress, when the environmental conditions under which they are reared are not optimal. The stress will be further amplified, if the feed is contaminated even with low levels of immunosuppressive agents like T-2 toxin leading to lowered immunity and increased risk of a disease (van der Zijpp, 1983; Monreal and Paul, 1989). Time and dose dependent mode of action of T-2 toxin in causing immunosupression increases susceptibility of birds to diverse array of pathogens including Salmonella (Ziprin and Elissalde, 1990; Sugita-Konishi et al., 1998). A significant interaction between $\mathrm{T}-2$ toxin and salmonella infection in chicken has also been reported (Boonchuvit et al., 1975). On the other hand, a concept of boosting immune status of the birds by incorporating certain critical nutrients in their feed has been gaining importance and has been referred to as 'Nutritional Immunomodulation' (Humphrey, 2005). Arginine (ARG) and vitamin E (VE) are two such nutrients which have been evaluated for their role in improving immune response in birds. Arginine is an essential amino acid in chickens because they do not possess a complete urea cycle (Tamir and Ratner, 1963) and VE is a potent antioxidant compound in biological systems. Their supplementation either individually or in combination has been observed to improve immune function (Lee et al., 2002; Li et al., 2007; Erf et al., 1998; Boa-Amponsem et al., 2000, Ramesh et al., 2016). ARG, as a substrate for immune system, regulates $\mathrm{T}$ cell development and function, B cell maturation and helps to generate nitric oxide as an effector molecule in activated tissue macrophages whereas vitamin $\mathrm{E}$ as an antioxidant, protects cells against immunopathology (Humphrey and Klasing, 2004). Yet, the immunomodulatory properties of these nutrients are achieved only when their levels in the diet are included above their requirement for the growth (Leshchinsky and Klasing, 2001, 2003). In light of the above considerations, the study detailed in this paper was conducted to evaluate the interaction of T-2 toxin at dietary levels which were commonly encountered in the field conditions with experimental $S$. gallinarum infection in commercial broiler chickens. The effect of ARG and VE supplementation in ameliorating the effect of this interaction was also probed into.

\section{Materials and Methods}

\section{T-2 toxin production}

The T-2 toxin was produced on whole wheat using Fusarium sporotrichoides MTCC 1894 (Burmeister, 1971) and was quantified by thin 
layer chromatography at Animal Feed Analytical and Quality Assurance Laboratory (AFAQAL), Veterinary College and Research Institute, Namakkal, Tamilnadu, India.

\section{S. gallinarum culture}

The reference culture of S. gallinarum was procured from the Division of Biological Standardization, Indian Veterinary Research Institute, Izatnagar - 243 122, Uttar Pradesh, India for challenge study. The organisms were grown in nutrient broth at $37^{\circ} \mathrm{C}$ for 24 hours. The growth was checked for purity and subjected to biochemical tests. The organism was confirmed as $S$. gallinarum according to Krieg et al., (1984).

The cell suspension was washed thrice in sterile normal saline solution under aseptic precautions. The harvested bacilli were suspended in normal saline solution to give a final concentration of $10^{7}$ organisms per 0.1 $\mathrm{ml}$ by using standard plate count method (Cruickshank, 1975).

\section{S. gallinarum and T-2 toxin interaction trial}

Ninety eight day-old commercial broiler chicks (Cobb) were procured from a reputed hatchery and fourteen birds were randomly allotted to each of the following groups and were fed control, toxin mixed and arginine and vitamin $\mathrm{E}$ supplemented feed from the day of hatch till the completion of trial on day 35. The birds in different groups were infected orally with $10^{7} \mathrm{CFU}$ of $S$. gallinarum per bird on $28^{\text {th }}$ day of study as depicted in the table below.

\begin{tabular}{|l|l|l|}
\hline Groups & Treatment & $\begin{array}{l}\text { S. gallinarum challenge } \\
(\mathbf{1 0} \text { CFU per bird })\end{array}$ \\
\hline I & Positive Control $(\mathrm{PC})$ & + \\
\cline { 2 - 3 } & Negative Control $(\mathrm{NC})$ & - \\
\hline II & T-2 toxin at $0.25 \mathrm{ppm}$ & + \\
\hline III & T-2 toxin at $0.50 \mathrm{ppm}$ & + \\
\hline IV & T-2 toxin at $1.00 \mathrm{ppm}$ & + \\
\hline V & $\begin{array}{l}\text { Arginine }(22 \mathrm{~g} / \mathrm{kg} \text { of feed }) \text { and Vitamin } \mathrm{E}(80 \mathrm{mg} / \mathrm{kg} \text { of } \\
\text { feed) supplementation }\end{array}$ & + \\
\hline VI & T-2 toxin at $1.00 \mathrm{ppm}+$ Arginine and Vitamin E & + \\
\hline
\end{tabular}

The broiler mash containing no toxin binders and free from mycotoxins and S. gallinarum was used in the experimental study. Weighed amounts of powdered wheat culture material containing known amounts of T-2 toxin was incorporated in the feed to yield three dietary levels of $0.25 \mathrm{ppm}, 0.5 \mathrm{ppm}$ and $1 \mathrm{ppm}$. LArginine (Sigma Aldrich) and VE (Tocopheryl acetate adsorbed on precipitated silicon dioxide from Mercks Pvt. Ltd., Goa) were mixed in the intended feed to have final supplementation rate of $22 \mathrm{~g} / \mathrm{kg}(2.2 \%)$ and $80 \mathrm{mg} / \mathrm{kg}$ respectively. The experimental trials were approved by the Institutional
Animal Ethics Committee and were conducted under its guidelines.

The following parameters were recorded to evaluate the effect of arginine and vitamin $\mathrm{E}$ supplementation on the interaction between $\mathrm{T}-2$ toxin and $S$. gallinarum:

\section{Growth rate study}

Body weights (g) of chicks were recorded at weekly intervals. Average weekly feed consumption (g) and feed conversion were arrived at as follows. 


$\begin{aligned} & \text { Feed } \\ & \text { consumption }\end{aligned}=\frac{\begin{array}{c}\text { Total feed consumed } \\ \text { during the week }(\mathrm{g})\end{array}}{\begin{array}{c}\text { Number of birds fed } \\ \text { during the week }\end{array}}$

Viable counts of $S$. gallinarum in liver

Six birds from each group were randomly sacrificed on days 3 and 7 PI after recording the clinical manifestations if any. Aseptically collected pieces of liver from each of the salmonella challenged bird were individually subjected to bacteriological examination to calculate the viable salmonella organisms per gram of liver tissue as per Hinton (1986).

Confirmation of $S$. gallinarum by PCR, targeting sefA gene

The DNA was extracted from samples of spleen, liver and heart of salmonella challenged birds from Group I (PC) and Group IV as per the standard protocol, using the "DNeasy ${ }^{\circledR}$ Blood and Tissue kit" procured from Qiagen, Inc., (USA). The purity and concentration of the extracted tissue DNA was estimated by UV spectrophotometry. The DNA thus extracted from different tissue samples from salmonella challenged birds were subjected to PCR. Polymerase chain reaction was performed using previously published primer pairs specific for sefA gene (Table 1) with PCR kit as per QIAGEN PCR protocol. Amplifications were carried out using conditions from Oliveira et al., (2002). All amplification reactions included a positive control (reference culture obtained from IVRI) and a no template control. The PCR products were analyzed by Gel electrophoresis on $2 \%$ agarose along side 250 bp DNA ladder. Following electrophoresis, the bands were visualized at $300 \mathrm{~nm}$ wavelength using a UV transilluminator and recorded on a gel documentation unit.

\section{Statistical analysis}

The data generated from different parameters of the experimental study were systematically classified and subjected to one way analysis of variance as per Snedecor and Cochran (1989) using SPSS17 statistical package.

\section{Results and Discussion}

\section{Clinical signs and mortality}

The salmonella infected birds showed clinical signs of dullness, inappetence, ruffled feathers and diarrhoea. The clinical observations drew support from the similar findings of earlier workers Kokosharov et al., (1997) and Ramesh et al., (2000). The signs were pronounced in toxin fed birds when compared to positive control. A bird in Group IV fed with 1 ppm of T-2 toxin died on day 5 PI.

Non-infected control birds (NC) remained healthy throughout the period of experimentation. ARG and VE supplemented birds with ' 0 ' level of T-2 toxin in their diet (Group V) exhibited mild sign of dullness initially till day 3 PI but recovered later on and remained apparently normal till the end of experiment. Immunomodulatory role played by ARG and VE combination (Ramesh et al., 2016) could be construed as reason for effective clearing of salmonella from the system and hence, initial mild clinical signs noticed in birds of this group subsided after day 4 PI.

\section{Growth parameters}

\section{Body weight and feed conversion ratio}

Mean $( \pm$ SE) body weights of broiler chickens in different treatment groups at the end of 
interaction trial on day 35 are presented in Figure 1. The salmonella infected birds in positive control group showed significantly lower body weights compared to the birds in negative control. The higher FCR recorded in positive control was however not significant compared to the negative controls. However, a significant increase in FCR of broiler birds after second week of salmonella challenge was reported by earlier workers (Ramesh et al., 2000a). The systemic infection that followed oral inoculation of $S$. gallinarum affecting liver and intestine could be the reason for poor efficiency exhibited.

Significantly lower body weights were observed in birds fed different dietary levels of T-2 toxin $(0.25,0.5$ and $1 \mathrm{ppm})$ for $0-28$ days and later challenged orally with salmonella on day 28 in comparison to the body weight of birds in negative control. However, unlike birds fed 0.5 and $1 \mathrm{ppm}$ of $\mathrm{T}-2$ toxin, the birds that were fed $0.25 \mathrm{ppm} \mathrm{T}$ 2 toxin recorded body weights similar to the birds in positive controls. Hence, it could be deduced that salmonella and T-2 interaction was noticed when the level of T-2 toxin was $0.5 \mathrm{ppm}$ and higher.

The FCR was higher at all the levels of dietary T-2 toxin when birds were challenged with salmonella on day 28 (Table 2). This pointed at the potentiality of $\mathrm{T}-2$ toxin at levels as low as $0.25 \mathrm{ppm}$ in impairing the production performance of broiler birds when an interaction occurs with an intestinal pathogen like salmonella.

Group V birds (ARG+VE) recorded mean ( \pm SE) body weights which were similar to birds in negative control and higher than the birds in positive control. Group VI (ARG+VE+T2@1ppm) birds showed body weights significantly $(\mathrm{P} \leq 0.05)$ higher than the birds fed with 1 ppm of T-2 toxin without ARG and VE supplementation (Group IV) and statistically comparable to body weight of birds in positive control.

\section{Viable counts of $S$. gallinarum in liver}

Mean $( \pm \mathrm{SE}) S$. gallinarum viable counts in liver were significantly $(\mathrm{P} \leq 0.05)$ higher in birds of Group IV compared to the counts in positive control (PC) birds on days 3 and 7 PI. However, the salmonella viable counts in birds fed with $0.5 \mathrm{ppm}$ of $\mathrm{T}-2$ toxin were significantly higher only on day 7 PI (Table 3 ). An interaction between T-2 toxin and the bacteria was thus evident. A pronounced inflammatory reaction in gastrointestinal tract had earlier been reported due to dietary T-2 toxin (Hoerr et al., 1981; Krishnamoorthy et al., 2007). And being a known intestinal pathogen $S$. gallinarum had the greater opportunity in T-2 toxin fed groups to breach the local protection in GIT and invade in larger number to subsequently appear in its important site of predilection, the liver. The resultant bacteremia would normally be combated by the phagocytic cells, but negative interaction on spleen size by $\mathrm{T}-2$ toxin resulting in a relatively smaller spleen (Ramesh et al., 2014) would have impaired the phagocytic cells of reticuloendothelial system and thus a compromised immune response. Further, regression of thymus and bursa in T-2 toxin fed birds put them under further immunosuppression hindering normal clearing of $S$. gallinarum from the system. A significantly lower $\mathrm{CD}^{+}$and $\mathrm{CD}^{+}$cells in peripheral blood of $\mathrm{T}-2$ toxin fed birds (Kamalavenkatesh et al., 2005; Ramesh et al., 2016) indicated a compromised CMI response which is the key arm of immune system to counteract intracellular pathogen, the Salmonella. Thus, viable counts of salmonella were significantly higher in toxin fed groups even on day 7 PI. Death of a bird in Group IV which received $1 \mathrm{ppm}$ of T-2 toxin on day 5 PI was a culmination of implications of this interaction. 
Table.1 Primers used for the identification of S. gallinarum (sefA gene)

\begin{tabular}{|c|c|c|c|c|}
\hline $\begin{array}{c}\text { Name of the } \\
\text { primer }\end{array}$ & $\begin{array}{c}\text { PrimerL } \\
\text { ength }\end{array}$ & Primer Sequencefrom 5'to 3' & $\begin{array}{c}\text { Amplicon } \\
\text { length(bp) }\end{array}$ & Reference \\
\hline sefA F & 21 & GATACTGCTGAACGTAGAAGG & 488 & Oliveira et al., 2002 \\
\hline sefA R & 24 & GCGTAAATCAGCATCTGCAGTAGC & & \\
\hline
\end{tabular}

Table.2 Feed Conversion Ratio in birds of different treatment groups at the end of interaction trial

\begin{tabular}{|c|c|c|c|c|c|c|c|}
\hline \multirow{2}{*}{ Particulars } & \multicolumn{2}{|c|}{ GROUPS } & IV & VI \\
\cline { 2 - 8 } & $\begin{array}{c}\text { I } \\
\text { Positive } \\
\text { Control }\end{array}$ & $\begin{array}{c}\text { Negative } \\
\text { Control }\end{array}$ & II & III & IV & \\
\hline \multirow{2}{*}{ FCR } & $1.74^{\mathrm{ab}} \pm 0.01$ & $1.69^{\mathrm{a}} \pm 0.01$ & $1.81^{\mathrm{c}} \pm 0.01$ & $1.88^{\mathrm{d}} \pm 0.008$ & $1.99^{\mathrm{e}} \pm 0.02$ & $1.71^{\mathrm{a}} \pm 0.01$ & $1.77^{\mathrm{bc}} \pm 0.01$ \\
\hline
\end{tabular}

Means bearing different superscripts differ significantly $(\mathrm{P}<0.05)$.

Table.3 The viable $S$. gallinarum counts in liver of salmonella challenged birds

\begin{tabular}{|c|c|c|c|c|c|c|}
\hline Particulars & \multicolumn{5}{|c|}{ GROUPS } \\
\cline { 2 - 8 } & I & II & III & IV & V & VI \\
\hline 3 DPI & $5.0 \times 10^{6 \mathrm{ab}} \pm 2.4 \times 10^{5}$ & $7.8 \times 10^{6 \mathrm{ab}} \pm 3.8 \times 10^{5}$ & $13.0 \times 10^{6 \mathrm{~b}} \pm 3.0 \times 10^{6}$ & $3.9 \times 10^{7 \mathrm{c}} \pm 6.7 \times 10^{6}$ & $5.5 \times 10^{4 \mathrm{a}} \pm 4.5 \times 10^{3}$ & $4.9 \times 10^{6 \mathrm{ab}} \pm 7.0 \times 10^{5}$ \\
\hline 7 DPI & $4.5 \times 10^{4 \mathrm{~b}} \pm 5.1 \times 10^{3}$ & $6.9 \times 10^{4 \mathrm{bc}} \pm 4.7 \times 10^{3}$ & $9.3 \times 10^{4 \mathrm{c}} \pm 2.5 \times 10^{3}$ & $2.8 \times 10^{5 \mathrm{~d}} \pm 3.4 \times 10^{4}$ & $2.7 \times 10^{2 \mathrm{a}} \pm 3.2 \times 10^{1}$ & $4.5 \times 10^{4 b} \pm 5.2 \times 10^{3}$ \\
\hline
\end{tabular}
Means bearing different superscripts within a row differ significantly $(\mathrm{P}<0.05)$.

Fig.1 Body weight (g) of birds in different treatment groups at the end of interaction trial

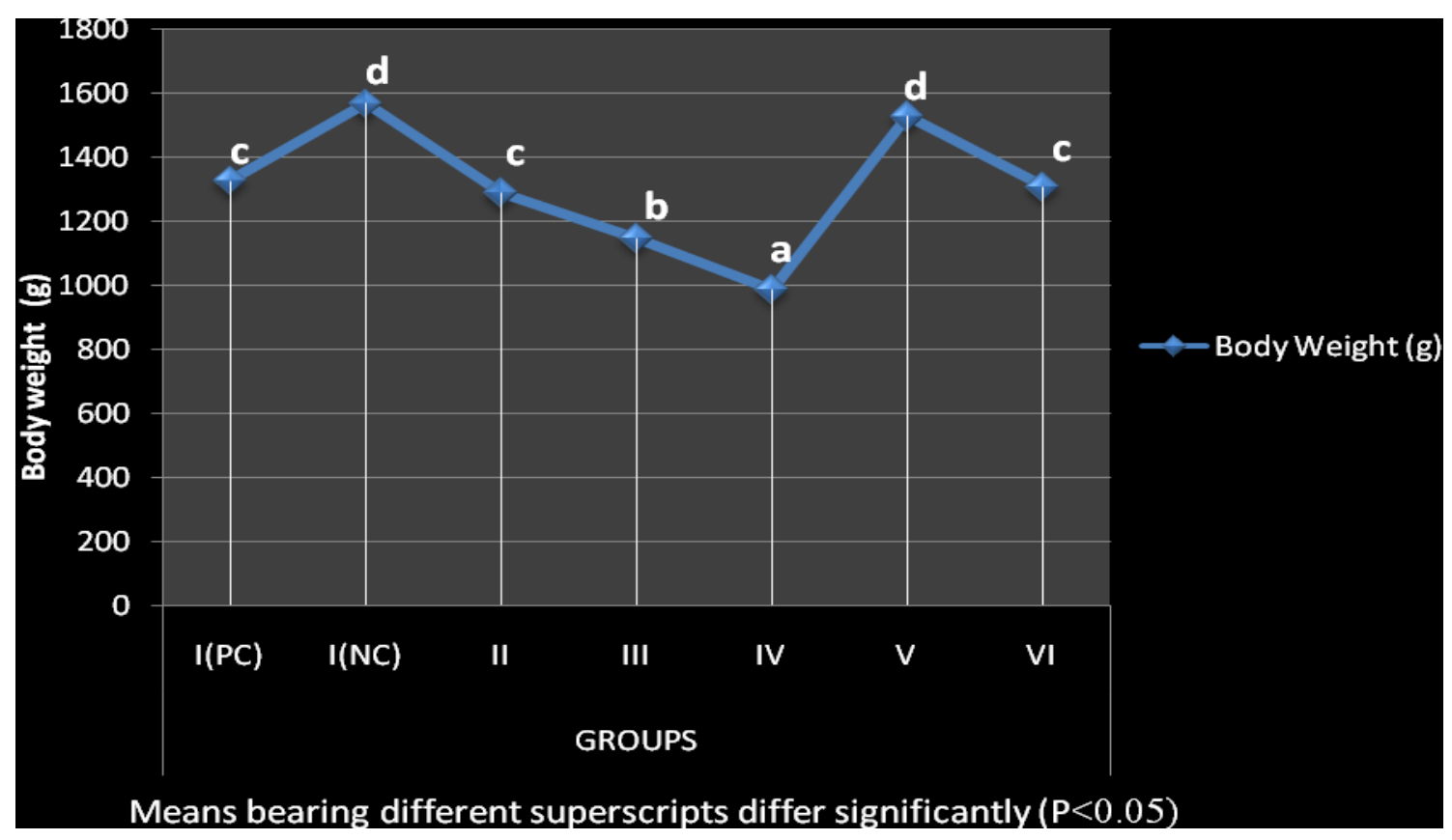


Fig.2 PCR amplification of sefA gene in different tissues of $S$. gallinarum challenged birds

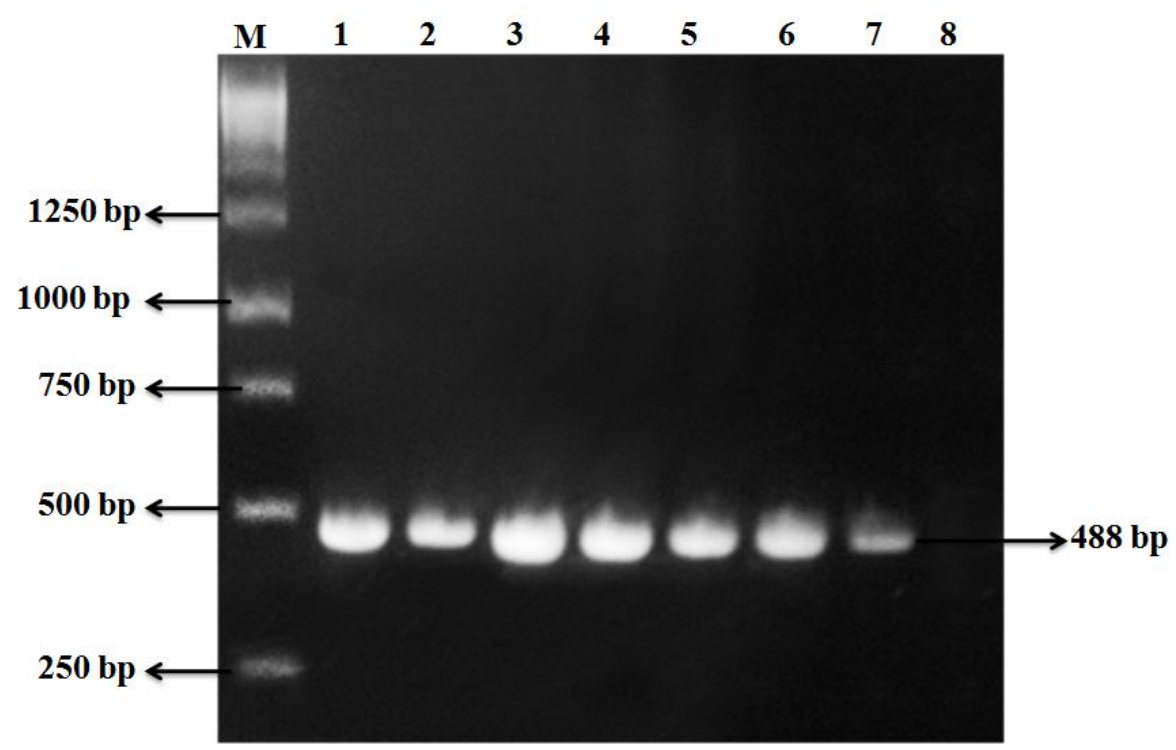

Lane M: 250bp DNA ladder

Lane 1: Spleen (Group IV)

Lane 2: Spleen (Group I)

Lane 3: Liver (Group IV)

Lane 4: Liver (Group I)

Lane 5: Heart (Group IV)

Lane 6: Heart (Group I)

Lane 7: Positive control (Reference culture from IVRI)

Lane 8: No template control.

Boonchuvit et al., (1975) reported a significant interaction resulting in increased mortality in chickens fed T-2 toxin and infected with salmonella organisms whereas profound loss of resistance to systemic salmonellosis in T-2 toxin treated birds was reported by Ziprin and Elissalde (1990). The findings of the present study were also in consensus with Richard et al., (1978) who concluded that the susceptibility to an infectious disease was considered to be mediated chiefly through a defect in the cell mediated immune system caused by $\mathrm{T}-2$ toxin in the diet.

Birds in Group V which were supplemented with ARG and VE in the control diet recorded minimum viable counts on both days PI, but the counts were significantly $(\mathrm{P} \leq 0.05)$ lower on day $7 \mathrm{PI}$ in comparison to the counts in positive control. A significant increase in peripheral blood $\mathrm{CD}^{+}$and $\mathrm{CD}^{+}$cells when arginine and vitamin $\mathrm{E}$ are supplemented either individually or in combination indicated a strong cell mediated immune response (Erf et al, 1998, Lee et al., 2002, Ramesh et al., 2016). This could be interpreted as the reason for convincing systemic clearance of salmonella resulting in significantly lower viable counts observed in the present study. Furthermore, ARG is a substrate to generate nitric oxide in activated tissue macrophages and sustained production of NO is the essential part of host defence to 
ward off systemic pathogens (Kidd et al., 2001). As birds cannot synthesis arginine de novo, its supplementation in the diet is critical for the host defense. So, supplementation of ARG in the diet of birds in the present study might have helped them in clearing off salmonella effectively from the system. T-2 toxin fed birds which received ARG and VE supplementation (Group VI) showed viable counts which were similar to the counts in control indicating the immunostimulatory role the combination of ARG and VE had played in minimizing the salmonella persistence in the system.

\section{Confirmation of $S$. gallinarum By PCR, Targeting sefA gene}

The DNA extracted from different tissue samples from salmonella challenged birds were subjected to PCR. The quality of DNA was measured in the UV spectrophotometer and $\mathrm{A}_{260} / \mathrm{A}_{280}$ ratio was found to be 1.7 to 1.9 which ensured the purity of DNA. Polymerase chain reaction was performed using previously published primer pairs specific for sefA gene with PCR kit (QIAGEN, Germany). All amplification reactions included a positive control (reference culture obtained from IVRI) and a no template control. The PCR products were analyzed by Gel electrophoresis on $2 \%$ agarose alongside 250 bp DNA ladder. The amplicon of $488 \mathrm{bp}$, which was specific to sefA gene was, resolved from all the tested samples of $S$. gallinarum challenged birds (Figure 2).

\section{References}

Barrow, P.A. and Freitas neto O.C., 2011. Pullorum disease and fowl typhoid new thoughts on old diseases: a review. Avian Pathol., 40(1): 1-13.

Boa-amponsem, K., Price, S. E., Picard, M., Geraert, P. A., and Siegel, P. B., 2000. Vitamin $\mathrm{E}$ and immune responses of broiler pureline chickens. Poult. Sci., 79:466-470.

Boonchuvit, B., Hamilton, P.B. and Burmeister, H.R., 1975. Interaction of T-2 toxin with Salmonella infections of chickens. Poult. Sci., 54: 1693-1696

Burmeister, H.R., 1971. T-2 toxin production by Fusarium trinctium on solid substrate. Appl. Microbiol., 21: 739-742

Corrier, D. E., 1991. Mycotoxicosis: Mechanisms of Immunosuppression. Vet. Immunol. Immunopathol., 30:7387.

Cruickshank, R., $1975 . \quad$ Medical Microbiology, $12^{\text {th }}$ Edn. Vol II published by Churchill Livingstone, 23 Revelston, Terrace, Edinburgh.

Devan Arora, Suresh Kumar, Naresh Jindal, Gulshan Narang, P. K. Kapoor, and N. K. Mahajan, 2015. Prevalence and epidemiology of Salmonella enterica serovar Gallinarum from poultry in some parts of Haryana, India. Vet World. 8(11): 1300- 1304.

Erf G. F., Bottje, W. G., Bersi, T. K., Headrick, M. D. and Fritts, C. A., 1998. Effects of Dietary Vitamin E on the Immune System in Broilers: Altered Proportions of CD4 T Cells in the Thymus and Spleen. Poult. Sci., 77:529-537.

Hinton, M., 1986. Letters in Applied Microbiology, 3:97

Hoerr, F. J., Carlton, W. W. and Yagen, B., 1981. Mycotoxicosis caused by a single dose of T-2 toxin or diacetoxyscirpenol in broiler chicken. Vet. Pathol., 18: 652654

Humphrey, B. D., 2005. Nutrient needs of the immune system. In: Proceedings of the 3rd Mid-Atlantic Nutrition Conference. Zimmermann, N.G., ed., University of Maryland, College Park, MD 20742. pp 58-69.

Humphrey, B.D. and Klasing, K.C., 2004. Modulation of nutrient metabolism and 
homeostasis by the immune system. World Poult. Sci. J., 60:90-100.

Kamalavenkatesh, P., Vairamuthu, S., Balachandran, C., Murali Manohar, B. and Dhinakar Raj, G., 2005. Immunopathological effect of the mycotoxins cyclopiazonic acid and T-2 toxin on broiler chicken. Mycopathologia, 159: 273-279.

Kidd, M.T., Peebles, E.D., Whitmarsh, S.K., Yeatman, J.B. and Wideman, R.F., Jr., 2001. Growth and immunity of broiler chicks as affected by dietary arginine. Poult Sci., 80 (11):1535-42

Kokosharov, T., Hristov, $\mathrm{H}$ and Belchev, L., 1997. Clinical, bacteriological and pathological studies on experimental fowl typhoid. Indian Vet. J., 74: 547549.

Kreig, N.R., Holt, J.G., Williams and Wilkins., 1984. Bergey's Manual of Systematic Bacteriology Vol. I. 428, East preston street, Baltimore, M.D. 21202, USA.

Krishnamoorthy, P., Vairamuthu, S., Balachandran, C. and Murali manohar. B., 2007. Pathology of chlopyriphos and T-2 toxin on broiler chicken. Veterinarski Archiv., 77: 47-57.

Lee, J. E., Austic, R. E., Naqi, S. A., Golemboski, K. A. and Dietert, R. R., 2002. Dietary arginine intake alters avian leukocyte population distribution during infectious bronchitis challenge. Poult. Sci., 81:793-798.

Leshchinsky, T.V. and Klasing, K. C., 2001. Relationship between the level of dietary vitamin $E$ and the immune response of broiler chickens. Poult. Sci., 80:1590-1599.

Leshchinsky, T.V. and Klasing, K.C., 2003. Profile of chicken cytokines induced by lipopolysaccharide is modulated by dietary alpha-tocopheryl acetate. Poult. Sci., 82:1266-1273.

Li, P., Yin, Y. L., Li, D., Kim, S. W. and Wu,
G., 2007. Amino acids and immune function. Br. J. Nutr., 98:237-252.

Monreal, G., and G. Paul., 1989. Infectious disease factors in poultry. Berl. Munch. Tierarztl. Wochenschr., 102:405-409.

OIE, Office International Des Epizooties, 2012. Fowl typhoid and pullorum disease. In: Manual of Diagnostic Tests and Vaccines for Terrestrial Animals. 7th ed. Paris: Office International des Epizooties, $p p$ 1-14.

Oliveira, S.D., Santos, L.R., Schuch, D.M.T., Silva, A.B., Salle, C.T.P. and Canal, C.W., 2002. Detection and identification of salmonellas from poultry-related samples by PCR. Veterinary Microbiology, 87:25-35.

Pestka, J.J. and Bondy, G.S., 1990. Alteration of immune function following dietary mycotoxin exposure. Can J Physiol Pharmacol., 68: 1009-1016.

Ramesh, B.K., M.L. Satyanarayana, R.N., Sreenivas Gowda, S.K. Vijayasarathi and Suguna Rao, 2000. Effect of Lactobacillus acidophilus on growth in Salmonella gallinarum infected birds. Indian J. Poult. Sci. 35(3): 338-340.

Ramesh, B.K., M. L. Satyanarayana, R.N., Sreenivas Gowda, S.K. Vijayasarathi and Suguna Rao. 2000a. Effect of Lactobacillus acidophilus on gut $\mathrm{pH}$ and viable bacterial count in experimental fowl typhoid in broilers. Indian Vet. J., 2000 77(2): 544 - 546.

Ramesh, B.K., Narayanaswamy, H.D., Satyanarayana, M. L., Suguna Rao and Srikrishna Isloor, 2014. Toxicological evaluation of T-2 toxin and its amelioration with arginine and vitamin E supplementation in broiler chicken. International Journal of Livestock Research, 4(2):74-80

Ramesh, B.K., Narayanaswamy, H. D., Satyanarayana, M. L. and Rao, S., 2016. Effect of dietary arginine and vitamin $\mathrm{E}$ on humoral and cell mediated immune 
response in experimental T-2 mycotoxicosis in broiler chicken. Journal of Cell and Tissue Research, 16(2): 5567-5574.

Richard, J.L., Cysewski, S.J., Pier, A.C., Booth, G.D., 1978. Comparison of effects of dietary T-2 toxin on growth, immunogenic organs, antibody formation and pathologic changes in turkeys and chickens. Am J. Vet Res.,39(10): 1674-1678.

Snedecor, G.W. and Cochran, W.G., 1989. Statistical Methods. $8^{\text {th }} E d n$. Iowa State Univ. Press, Ames.

Sugita-Konishi, Y., Hara, K.Y., Kasuga, F. and Kumagai, S., 1998. The effects of trichothecenes on host defense against infectious diseases. Maikotokishin (Tokyo), 47: 19-23.

Tamir, H. and Ratner, S., 1963. Enzymes of arginine metabolism in chicks.Arch. Biochem. Biophys., 102:249-258.

Van Der Zijpp, A. J., 1983. Breeding for immune responsiveness and disease resistance. World's Poult. Sci. J., 39:118-131.

WHO, World Health Organization, 2002. Evaluation of certain mycotoxins in food. WHO Techn Rep Ser 906. Geneva.

Ziprin, R.L. and Elissalde, M.H., 1990. Effect of T-2 toxin on resistance to systemic Salmonella typhimurium infection of newly hatched chickens. Am. J. Vet. Res.,51: 1869-1872.

\section{How to cite this article:}

Ramesh, B.K., H.D. Narayanaswamy, M.L. Satyanarayana, Suguna Rao and Srikrishna Isloor. 2019. Interaction of Different Dietary Levels of T-2 Toxin with Experimental Salmonella Gallinarum Infection in Broiler Chicken and its Amelioration with Arginine and Vitamin E Supplementation. Int.J.Curr.Microbiol.App.Sci. 8(04): 2232-2241. doi: https://doi.org/10.20546/ijcmas.2019.804.260 